\title{
The Estimation of Dose Relationships for the Inhalation of Radon and the Difference in Activities During the Year Using RAD7 in Iraq
}

\author{
Yousif Muhsin Zayir AL-Bakhat ${ }^{1}$, Batool Fayidh Mohammed ${ }^{2}$, Takrid Muneam Nafae ${ }^{1}$, \\ Nidhala H. K. AL-ANI' ${ }^{2}$, Abbas Alamiry ${ }^{1}$ \\ ${ }^{1}$ Radiation and Safety Directorate, Ministry of Science and Technology, Baghdad, Iraq \\ ${ }^{2}$ Department of Physics, College of Science for Women, University of Baghdad, Baghdad, Iraq
}

Email address:

Batool.faydh@yahoo.com (B. F. Mohammed), Taghreed_nafea@yahoo.com (T. M. Nafae)

\section{To cite this article:}

Yousif Muhsin Zayir AL-Bakhat, Batool Fayidh Mohammed, Takrid Muneam Nafae, Nidhala H. K. AL-ANI, Abbas Alamiry. The Estimation of Dose Relationships for the Inhalation of Radon and the Difference in Activities During the Year Using RAD7 in Iraq. Science Journal of Energy Engineering. Vol. 5, No. 5, 2017, pp. 109-123. doi: 10.11648/j.sjee.20170505.11

Received: July 1, 2017; Accepted: July 18, 2017; Published: October 31, 2017

\begin{abstract}
Exposure to radon and its daughters is one of the important contributions for radiation doses to the publics. In this study, concentrations of radon gas were measured in air at Al-Tuwaitha Nuclear Site and some surrounding areas. Measurements were achieved by RAD7 (radon detector), manufactured by DURRIDGE COMPANY Inc. Indoor radon concentration plays a vital role in the total effective dose in the indoor environments. The measurement of the indoor radon concentrations ranged from $(4.96 \pm 4.4$ to $102 \pm 25) \mathrm{Bq} / \mathrm{m}^{3}$ this high value of radon has been found at Decommissioning Directorate /emergency room, which is lower than the action value recommended by the EPA (Environmental Protection Agency) which is $\left(148 \mathrm{~Bq} / \mathrm{m}^{3}\right)$ while the lowest value has been founded in the Central Laboratories Directorate $\backslash$ models Room. These values were used to calculate the annual effective dose, the dose exposed to the soft tissues other than the lungs

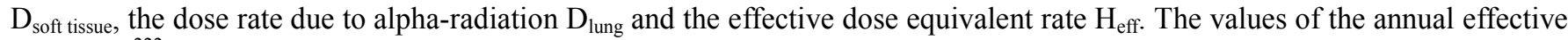
doses for ${ }^{222} \mathrm{Rn}$ inhalation by the people were calculated and ranged from $(0.124992$ to 2.5704$) \mathrm{mSv} / \mathrm{y}$ these result are lower than the value of $(10 \mathrm{mSv} / \mathrm{y})$ recommended by the ICRP (International Commission on Radiological Protection). It has been observed that winter concentration of indoor radon are greater than summer concentrations. The higher amount in the winter is attributed to the observation that people normally keep their windows closed during the winter, allowing indoor radon concentrations to rise. The lower radon concentrations in the summer might occur because people often open their windows, allowing low-radon outside air to enter the home. The results from this study show that the region has background radioactivity levels within the natural limits.
\end{abstract}

Keywords: Radon, Al-Tuwaitha Nuclear Site, RAD7

\section{Introduction}

Ecological contamination has existed for quite a long time yet just began to be critical after the mechanical unrest in the nineteenth century. Contamination happens when the environment can't devastate a component without making mischief or harm to itself. The components included are not created by nature, and the way toward eliminating can change from a day to a great many years (that is, for example, the case for radioactive pollutants). At the end of the day, contamination happens when nature couldn't break down a component that has been acquired to it an unnatural way. So it is vital for us to be delicate and dynamic against every one of the pollutants making dangers our lives and this is the main reason for this study to ensure there is no huge contamination in our country and to guarantee the safety for the workers at Al-Tuwaitha nuclear site, also the people that live close by to the site [1].

\subsection{Radon and Its Progeny}

The normally radioactive noble gas radon $\left({ }^{222} \mathrm{Rn}\right)$ can be found in soil, water, outside and indoor air [2]. It is 
accordingly inescapable source of radiation introduction both at home and at work. High radon levels in air can happen in building, including working environments, in some geological areas. This applies especially in work environments such underground mines, normal holes, burrows, medicinal treatment, characteristic hollows, burrows, restorative treatment territories like spas, and water supply offices where ground water with a high radon fixation is put away [3].

Three radioactive isotopes of radon happen normally in critical amounts:

${ }^{222} \mathrm{Rn},{ }^{220} \mathrm{Rn}$ and ${ }^{219} \mathrm{Rn}$. Radon-222 has a half-existence of 3.82 days and is gotten from the characteristic radioactive decay chain headed by ${ }^{238} \mathrm{U}$. Radon- 220 has a half-existence of 55.6 seconds and is gotten from the normal radioactive decay chain headed by ${ }^{232} \mathrm{Th}$, Radon-219 has a half-existence of 3.96 seconds and is gotten from the characteristic radioactive decay chain headed by ${ }^{235} \mathrm{U}$ [3] Attributable to its short half-life and the generally low groupings of ${ }^{235} \mathrm{U}$ in soils, the dose from exposure due to ${ }^{219} \mathrm{Rn}$ is negligible and is therefore not of radiological concern. shows the decay data of ${ }^{222} \mathrm{Rn}$ and ${ }^{220} \mathrm{Rn}$ and the principle decay information of these radionuclides are given. Recorded the radioactive half-life (T), the radioactive decay constant (A), the emitted main energies and their relative intensities.

\subsection{Radon in Air (Outdoor and Indoor)}

The primary source of exposure to radon is indoor or household air. Many houses and structures have been built appropriate on top of radon emanating rocks. Radon daughters are regularly attached to dust, and we are exposed to them primarily through breathing. They are available in almost all air. Be that as it may, background levels of radon in outdoor air are for the most part very low, around 0.003 to 2.6 picocuries of radon for each liter of air. In indoor areas, for example, homes, schools, or office buildings, levels of radon and daughters are by and large higher than outdoors levels. Breaks in the foundation or basement of our home may permit expanded measures of radon to move into our homes. In a few territories of the country the measure of uranium and radium in rock type, for example, phosphate rock or stone, is high. In these territories radon levels in open air will for the most part be higher [4].

\subsection{Ways for Entering the Radon to Dwelling}

It's important to understand the sources of radon gas and its ways for entering houses before we attempted to control its level in dwelling which suffer from high radon levels, so we can limit it by the following: the levels of radon gas in dwelling are determined by the balance between the entry rate and the Removal rate which mainly determined by the Ventilation. Since the ventilation rate is limited inside dwelling in bigger way than its entry rate, so the main reason for the disparity in radon activity inside dwelling is because the entry rate for radon gas to dwelling is unequal. Important point we should mention is the sources of radon is soil, water and building material [5]. The pressure difference between the ground and the building on it causes radon gas to seep from one to another, so if the air pressure inside the dwelling or any kind of building generally was less than in soil the penetrating of radon gas into building will increase because it moves from the places that have high pressure to the places that have low pressure. The pressure difference can gets high or low according to the wind and the temperature difference between indoor and outdoor. This variation in temperature and pressure may lead for pulling the air from down (ground) to up (buildings) where the low pressure is found because usually the pressure inside buildings is lower than in the ground and it can get lower when we turn on the furnace or the oven, using the bathroom and Ventilation fans, so pressure drop by several Pascal (one pascal equals one newton per square meter) is enough to pull the air that contains radon from outdoor to indoor [6].

Radon can also be found in groundwater from private or small community wells. Radon produced in the ground can dissolve and accumulate in water from underground sources such as wells. When water containing radon is agitated during daily household use, showering, clothes washing or cooking, the radon gas could be released into the air. Research has shown that drinking water which contains radon is far less harmful than breathing the gas. The health risk does not come from consuming the radon, but from inhaling the gas [7].

\subsection{Simple Ways for Lowering Radon Ratio in Homes}

In spite of discovering the existence of radon gas in houses and lowering it ratio present a big challenge for each of us, we can lower its risk ratio which we are exposed to it for being in home, whether we make sure that radon gas is seeping into our house or not there is a simple solutions that is Accessible to each of us for the protection from the risk from this hidden killer. These solutions are:

(a). Spending less time in places where there are high levels of radon such as low places like the basements.

(b). Opening all the windows and turn on fans to increase air flow through the house whenever possible, especially in places prone to gas, such as the basement and interior.

(c). Closing the sinks and cover them to reduce the chance of leakage of radon inside the house, and if it must be used daily, it must be installed a water trap, which traps the places of leakage of radon gas.

(d). Keep the ventilation holes open throughout the year in the narrow or low-lying areas located at the bottom and sides of the house.

(e). Stop smoking, and urged others not to smoke inside the house. [8].

\subsection{Health Risk of Radon Exposure}

$\mathrm{Rn}^{222}$ is a naturally occuring radioactive gas that is in charge of roughly $50 \%$ of the annual background radiation exposure globally. Endless exposure to radon and its decay 
products is evaluated to be the second leading reason for lung cancer behind smoking, and connections to different types of neoplasms have been proposed. As radon decays, it produces radioactive progeny and emits sighnficant levels of alpha radiation, alongside lower levels of beta and gamma radiation, of different energies prompting organic harm that can be hazardous to human wellbeing [9].

A connection amongst radon and lung carcinogenesis has as of now been set up and radon is thought to be the second driving reason for lung cancer in the UK after smoking [10], with confirmation of a synergistic impact amongst radon and tobacco smoke [11]. More noteworthy than half of the normal yearly foundation radiation dosage is because of radon and its decay products, which, because of electrostatic powers, can join to aerosols and plateout on the skin fundamentally expanding the potential dose conveyed to this organ [12].

Alpha particles speak to the dominating type of radiation produced therefore of the decay of radon. In spite of their restricted tissue pentration capacity, alpha particles can bring about huge biological harm in presented tissue because of their high relative biological effectiveness (RBE) [13]. Beta and gamma-radiation are likewise discharged from the decay of radon progeny, however the RBE contrasted with alpha particle ionization is insignificant [14].

Like other ecological pollutants, there is some instability about the greatness of radon health dangers. Be that as it may, we find out about radon dangers than dangers from most other cancer-causing substances. This is on account of appraisals of radon dangers depend on investigations of canser in people (underground miners). Smoking compined with radon is a particularly genuine wellbeing hazard. In light of many reviews Radon is evaluated to bring about around 21,000 lung canser passings for every year. Quiting smokes and lowering our radon level to decrease our lung cancer hazard. Kids have been reported for to have more serious hazard than grown-ups of certain sorts of disease from radiation, yet there are right now no decisive information on whether kids are at more serious hazard than grown-ups from radon.

\subsection{Alpha Particles}

Alpha particles comprise of a helium core (two protons and two neutrons) and can possibly store a lot of energy as they cross matter. In contrast with beta particles (electrons) and gamma radiation (photons) they are portrayed as having a high linear energy transfer (LET). Essentially subsequently of this high-LET order, alpha particles are more biologically significant than either beta or gamma radiations, responding significantly more promptly with DNA and producing oxidative stress through radiolysis in spite of their lessened penetrating capacity. Tissue regions and cell types that are inside depths traversableby alpha particle exposure can be especially vulnerable to organic harm. The most generous alpha producers from radon decay are polonium-218 (6.0 $\mathrm{MeV})$ and polonium-214 (7.69 MeV) and have of $47 \mu \mathrm{m}$ and $70 \mu \mathrm{m}$ respectively [15], recommending abnormal amounts of radiation, especially of the bronchial epithelium and at bifurcation locales, when breathed in into the lungs [16, 17]. Alpha Particles Are Strong Enough To Pit Plastic.

\subsection{The Cellular and Molecular Carcinogenic Effects of Radon Exposure}

Ionizing radiation as alpha particles can causeDNA harm from chromosomal variations [19] double strand DNA breaks and create responsive oxygen species (ROS), bringing about cell cycle shortening, apoptosis and an expanded potential for carcinogenesis [20].

It has already been expected that the profundity of skin would be too thick for alpha particles to effectively infiltrate and give adequate exposure to the destinations helpless against mutagenesis. Notwithstanding, research now proposes that introduction to zones of the skin that are especially thin, for example, on the face where epidermal thickness has been measured to be 10-40 $\mu \mathrm{m}$ [21] could bring about huge presentation of the basal layer to alpha radiation [22], hypothetically improving the probability of the potential for biological harm. The South-West of England has both the most noteworthy rates of non-melanoma skin cancer (NMSC) and the most noteworthy average radon concentrations in the UK, with epidemiological proof now proposing that in Devon and Cornwall expanded household private radon presentation might be a hazard consider for the improvement of squamous cell carcinoma of the skin [23]. It ought to be noticed that various different cancers have additionally been recommended to have an expanded hazard with high radon concentrations including leukemia and gastrointestinal malignancies, albeit any confirmation of a cause-impact relationship stays theoretical [24, 25].

\section{Materials and Methods}

\subsection{Area of Study}

Baghdad city is located in the Middle of Iraq and it is the capital of the Republic of Iraq. Its location of latitude 33.316666 and longitude 44.416668 it is located about 34 meters above sea level, with a total area nearly of $204.2 \mathrm{~km}^{2}$ and a population nearly of 7665292 inhabitants. See figure 1 . Baghdad city has a desert climate characterized by extreme heat during the day, an abrupt drop in temperature at night, and slight, erratic rainfall. The temperature is moderate at $12^{\circ} \mathrm{C}$ in winter and $33^{\circ} \mathrm{C}$ in summer. Its lands are flat and leveled in areas linked to waters from the Tigris River.

Al Tuwaitha nuclear site is situated on the Tigris and Euphrates floodplain that is a couple of kilometers from the edges of Baghdad. The facility is encased by a sand berm four miles $(6.4 \mathrm{~km})$ around and 160 feet $(50 \mathrm{~m})$ high. Al Tuwaitha nuclear site is situated around $1 \mathrm{~km}$ east of the Tigris Waterway $18 \mathrm{~km}$ south of Baghdad which covers a range roughly $1.3 \mathrm{~km}^{2}[26,27]$ as shown in figure 2 . In spite of the long history of atomic projects at Al Tuwaitha nuclear site there is no huge radioactive pollution as an outcome of typical methodology has been authoritatively expressed for the site or for the encompassing social orders. 


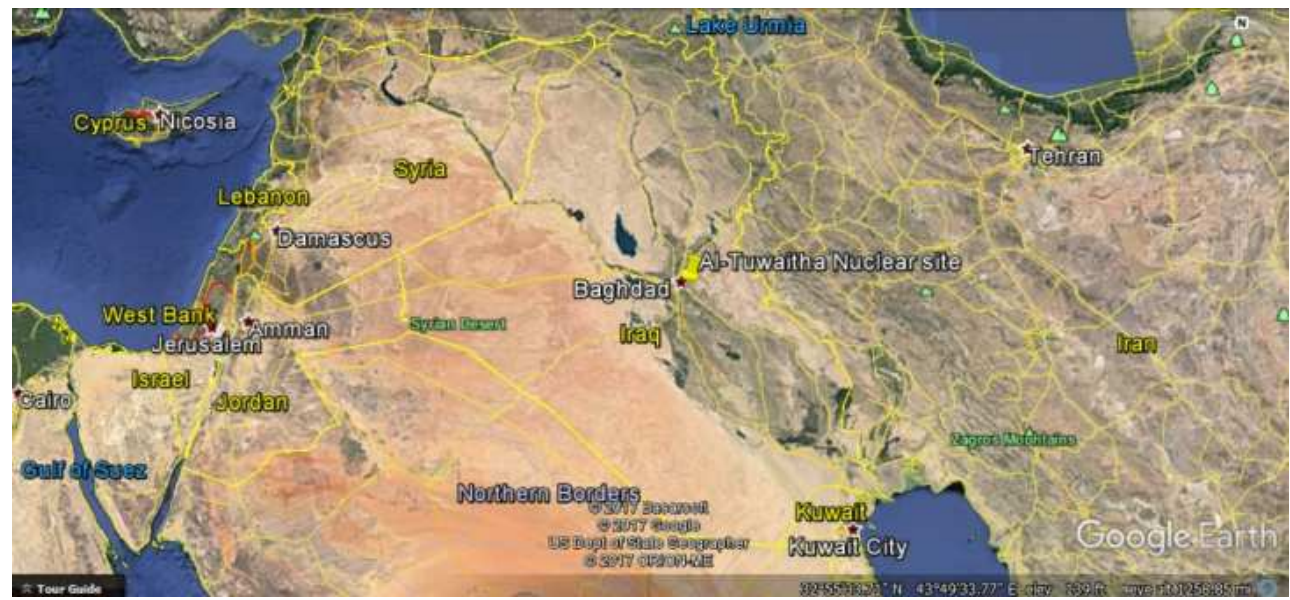

Figure 1. Iraq country photo, taken from google earth.

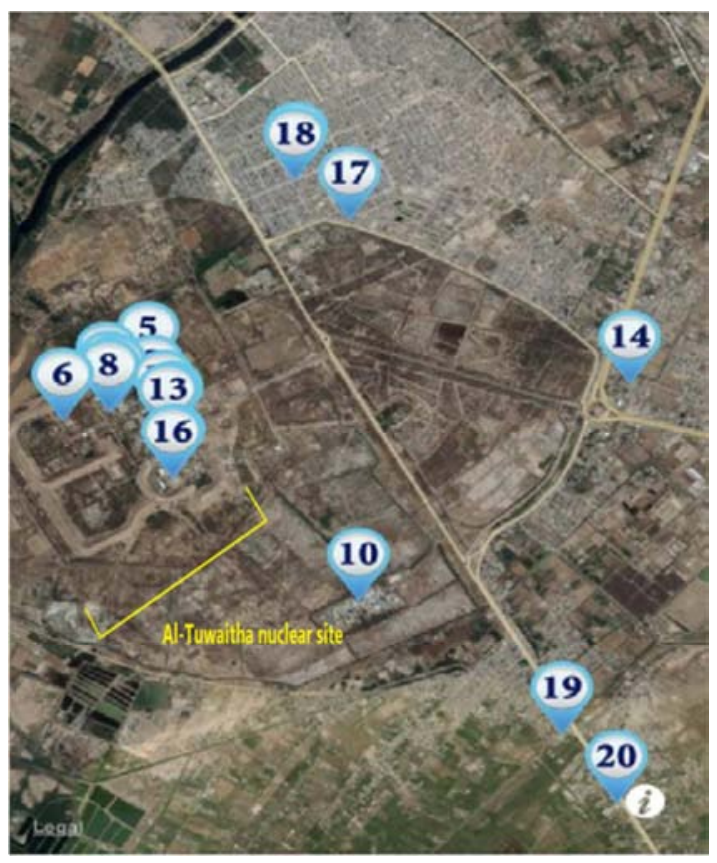

Figure 2. A photo shows the location of Al-Tuwaitha Nuclear Site.

\subsection{The Experimental Method for Measuring Radon}

In this section the method and technique that used for measuring the radon activity concentration is described. There are several measuring devices to measure radon levels including alpha track detectors, activated charcoal absorption devices and the Alpha GUARD monitor. The RAD7 radon detector manufactured by Durridge Company Inc. as shown in figure 3 has been used for the radon concentration measurement in the soil and air samples. The lower limit of detection (LLD) is less than $0.37 \mathrm{~Bq} \mathrm{~L}^{-1}$.

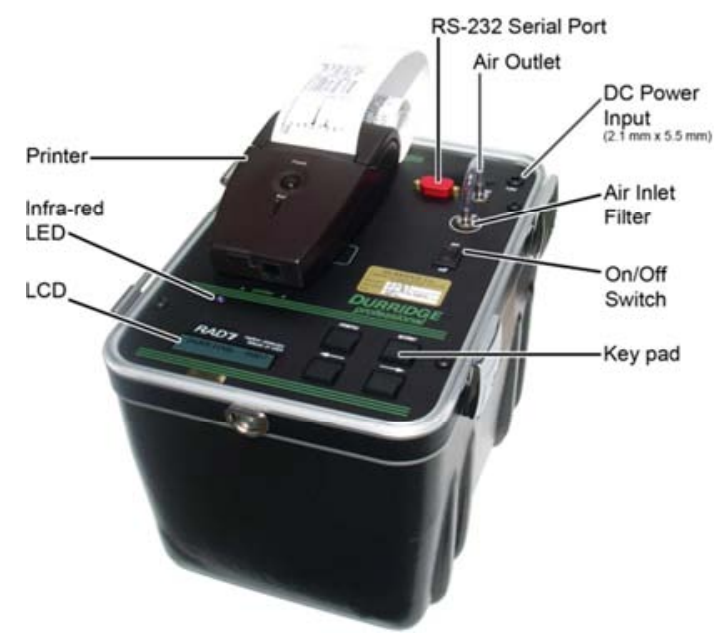

Figure 3. The RAD-7 radon detector [28]. 
RAD7 is continual radon measuring device from Durridge Company (USA). RAD7 is an active, high performance, which is extensively used because it is rugged and simple to use, produces a long-term integrated read out and is highly sensitive to alpha-particle radiation. The RAD7 is a Sniffer that uses the 3-minute alpha decay of a radon descendant, without intrusion from other radiations, and the instantaneous alpha decay of a thoron daughter. The RAD-7 uses silicon as a semiconductor material which converts the energy of $\alpha$ particles directly into electrical signals. The measuring range is between 4 to $750000 \mathrm{~Bq} \mathrm{~m}^{-3}$. The sampled air enters an interaction chamber and the relative humidity, temperature and battery voltage are all parameters that are worth observing. Table (1) shows more functionality of RAD-7 detector.

\subsection{RAD-7 Solid State Detector}

The DURRIDGE RAD7 utilizes a solid state alpha detector. A solid state detector is a semiconductor material (normally silicon) that proselytes alpha radiation straightforwardly to an electrical signal. One imperative preferred standpoint of solid state devices is toughness. Another favorable position is the capacity to electronically decide the energy of every alpha molecule. This makes it conceivable to tell precisely which isotope (polonium-218, polonium-214, etc.) produced the radiation, so that you can immediately distinguish old radon from new radon, radon from thoron, and signal from noise. This technique, known as alpha spectrometry, is a tremendous advantage in sniffing, or grab sampling, applications. Very few instruments other than the RAD7 are able to do this.

The RAD-7 possesses an internal sample cell of about 0.7 liter and has a hemispherical shape as can be observed in Figure 4. The inside of the hemisphere is coated with an electrical conductor which can changed, with a high voltage power supply, to a potential of about 2000-2500 Volts relative to the detector. This creates an electrical field throughout the cell. The electrical field propels the positively charged particles onto the detector in the periodic-fill cell. A decaying $222 \mathrm{Rn}$ atom within the cell leaves behind a positively charged $218 \mathrm{Po}$, which is accelerated onto the detector and sticks to it. The 218Po nucleus has a relatively short half-life and when it decays, it will have a $50 \%$ chance of entering the detector where it will produce an electrical signal, and the energy of the alpha particle can be identified. The RAD7 amplifies, filters, and sorts the signals according to their strength. In Sniff mode, the RAD7 utilizes just the polonium-218 signal to decide radon concentration, and the polonium-216 signal to decide thoron concentration, disregarding the resulting and longer-lived radon daughters. Along these lines, the RAD7 accomplishes quick reaction to changes in radon concentration, and quick recovery from high concentrations.

Table 1. Functionality of RAD-7 detector [29].

\begin{tabular}{|c|c|c|}
\hline No. & Specifications & Information \\
\hline \multirow{7}{*}{1} & \multirow{6}{*}{ Modes of operation } & SNIFF Rapid response and rapid recovery radon measurement \\
\hline & & THORON Radon and thoron measured simultaneously and independently \\
\hline & & NORMAL High sensitivity \\
\hline & & AUTO Automatic switch from SNIFF to NORMAL after three hours run \\
\hline & & GRAB Analysis of grab samples \\
\hline & & WAT Automatic analysis of water samples with RAD H2O accessory \\
\hline & \multirow{8}{*}{ Measurements types } & Radon in air with Sniff protocol for quick, spot reading \\
\hline \multirow{7}{*}{2} & & Thoron in air for searching for radon entry points \\
\hline & & Radon in air 1-day, 2-day or weeks protocol for long term measurement \\
\hline & & Radon in water batch samples with RAD H2O and Big Bottle System \\
\hline & & Continuous radon in water with RAD AQUA and Radon-in-Water Probe \\
\hline & & Radon in soil gas with Soil Gas Probe and Active DRYSTIK \\
\hline & & Radon emission from soil and hard surfaces with surface emission chamber \\
\hline & & Bulk radon emission from bulk materials and objects \\
\hline 3 & Sensitivity & 0.0470 in $\left(\mathrm{dps} / 150 \mathrm{~Bq} \mathrm{~m}^{-3}\right)$ or $2.80 \mathrm{in}(\mathrm{cpm} / 4 \mathrm{pCi} / \mathrm{L})[31]$ \\
\hline 4 & Range & $0.1-10,000 \mathrm{pCi} / \mathrm{L}\left(4-400,000 \mathrm{~Bq} / \mathrm{m}^{3}\right)$ \\
\hline 5 & Memory & $\begin{array}{l}\text { 1,000 radon concentrations and associated data. Can be read out on LCD, downloaded to PC and/or printed out } \\
\text { on HP IR printer. Summary of run shows high, low, average and standard deviation of readings }\end{array}$ \\
\hline 6 & Principle of operation & Electrostatic collection of alpha-emitters with spectral analysis \\
\hline 7 & Power supply & $\begin{array}{l}\text { AC or battery powered - } 5 \mathrm{AH} 6 \mathrm{~V} \text { batteries; automatic battery charge when plugged in and switched on; } \\
\text { optional low voltage input }\end{array}$ \\
\hline \multirow{2}{*}{8} & \multirow{2}{*}{ Print Output } & Short, medium or long format data printed after each cycle \\
\hline & & Run summary printed at end of run, including averages and spectrum \\
\hline 9 & Dimensions & $24 \times 19 \times 27 \mathrm{~cm}$ \\
\hline \multirow[t]{7}{*}{10} & Weight & $5 \mathrm{~kg} \quad$ \\
\hline & \multirow{3}{*}{ Sample Pumping } & Built-in pump draws sample from chosen sampling point \\
\hline & & Flow rate typically $800 \mathrm{ml} / \mathrm{min}$ \\
\hline & & GEIGER Tone beeps for radon and thoron counts \\
\hline & Audio Output & CHIME Chime only at the end of each cycle, otherwise silent \\
\hline & & OFF No sound \\
\hline & Tamper Resistance & TEST LOCK command locks keypad to secure against tampering \\
\hline
\end{tabular}




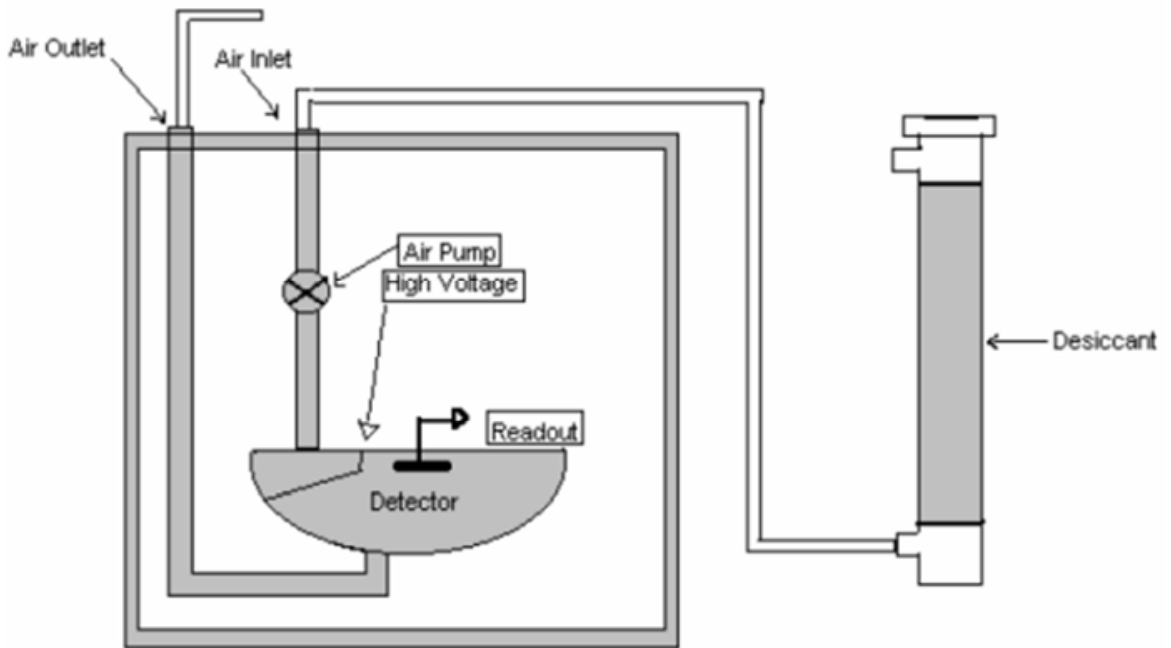

RAD7 Radon Monitor

Figure 4. Schematic diagram of the RAD-7 detector [32].

\subsection{RAD-7 Spectrum Analysis}

The RAD7 spectrum (see figure 5) is a scale of alpha energies from 0 to $10 \mathrm{MeV}$. Of particular interest are the radon and thoron daughters that produce alpha particles in the range of 6 to $9 \mathrm{MeV}$. When the radon and thoron daughters, deposited on the surface of the detector, decay, they emit alpha particles of characteristic energy directly into the solid state detector. The detector produces an electrical signal. Electronic circuits amplify and condition the signal, then convert it to digital form. The RAD7's microprocessor picks up the signal and stores it in a special place in its memory according to the energy of the particle. The accumulations of many signals results in a spectrum. The RAD7 divides the spectrum's 0 to $10 \mathrm{MeV}$ energy scale into a series of 200 individual counters, each representing a $0.05 \mathrm{MeV}$ channel. Whenever the RAD7 detects an alpha particle, it increments one of these 200 counters by one. Every so often, the RAD7 manipulates, condenses, prints out and stores data to long-term memory. Then it resets all 200 counters to zero, and begins the process a new.

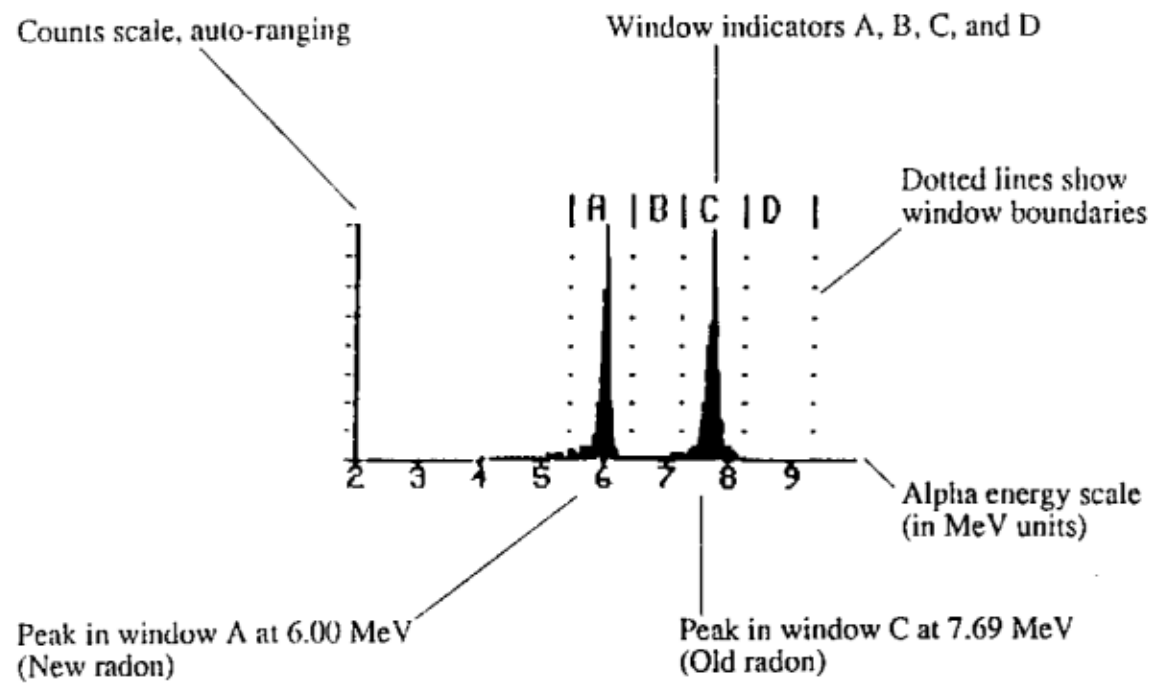

Figure 5. RAD7 alpha spectrum-218 Po (window A) and 214 Po (window C) taken from capture software.

The idealized spectrum of a $6.00 \mathrm{MeV}$ alpha emitter looks like a single needle-thin spike at exactly $6.00 \mathrm{MeV}$.

The RAD7 groups the spectrum's 200 channels into 8 separate "windows" or energy ranges. Window A, for example, covers the energy range of 5.40 to $6.40 \mathrm{MeV}$. So window A incorporates the $6.00 \mathrm{MeV}$ alpha molecule from polonium-218. The initial move toward changing over crude ghastly information to radon estimation is to include every one of the numbers in every window and divide by the detector "live time" or duration of dynamic information accumulation. The RAD7 microprocessor does this assignment and stores the outcomes to memory in this shape. We can review and print window information from past estimation. The RAD7 includes windows $\mathrm{E}, \mathrm{F}, \mathrm{G}$, and $\mathrm{H}$ 
together to shape window $\mathrm{O}$ (for "other") before putting away the information to memory. Spectrum printouts obviously check windows A, B, C, and D with dotted lines.

\subsection{Capture Software}

Capture is intended to simplify the transfer of data from the RAD7 to a computer, and its subsequent analysis. Capture software is a program that installed on the computer to analyze the reading that was stored in the RAD7 to form a Database as shown in the figure 6. the durridge capture software can perform additional calculations and corrections:

(a). The information of the reading in a high degree of clarity and it can be handled easily.

(b). Date, time and battery voltage rate for each reading.

(c). Temperature, relative humidity and applying the required correction. On them in case if the humidity increases above $10 \%$.

(d). (B) Window to (A) window spill correction. This is important when measuring low radon levels in the presence of high thoron.

(e). The Spectrum Panel which displays a synthetic representation of the spectrum printed out by the RAD7. It indicates alpha energies signaling the presence of radon and thoron daughter particles. (f). Knowing the protocol and the sequence for each reading.

(g). A graph between the concentration of radon and the time of measuring.

(h). We can compare between the different concentrations for radon.

(i). Forced Sniff mode: For long-term

(j). measurements, the RAD7 is normally put in

(k). Auto mode, in which the measurement starts

(1). Forcing a Sniff mode so as to achieve a fast initial response, before automatically switching to Normal mode after three hours, when the 214- Po decays have nearly reached equilibrium with the radon concentration. This assumes that the radon concentration is steady. If it appears that rapid changes in radon concentration were taking place, the user can, in CAPTURE, force the graph to display the data as if the RAD7 stayed in Sniff mode throughout the measurement, and thus see the rapid changes with a measurement time constant of just 12 minutes.

(m). We can combine the data from two or more RAD7 files in order to view separate runs in the same graph window, decrease uncertainty for tests done at the same time in the same location with separate RAD7s.

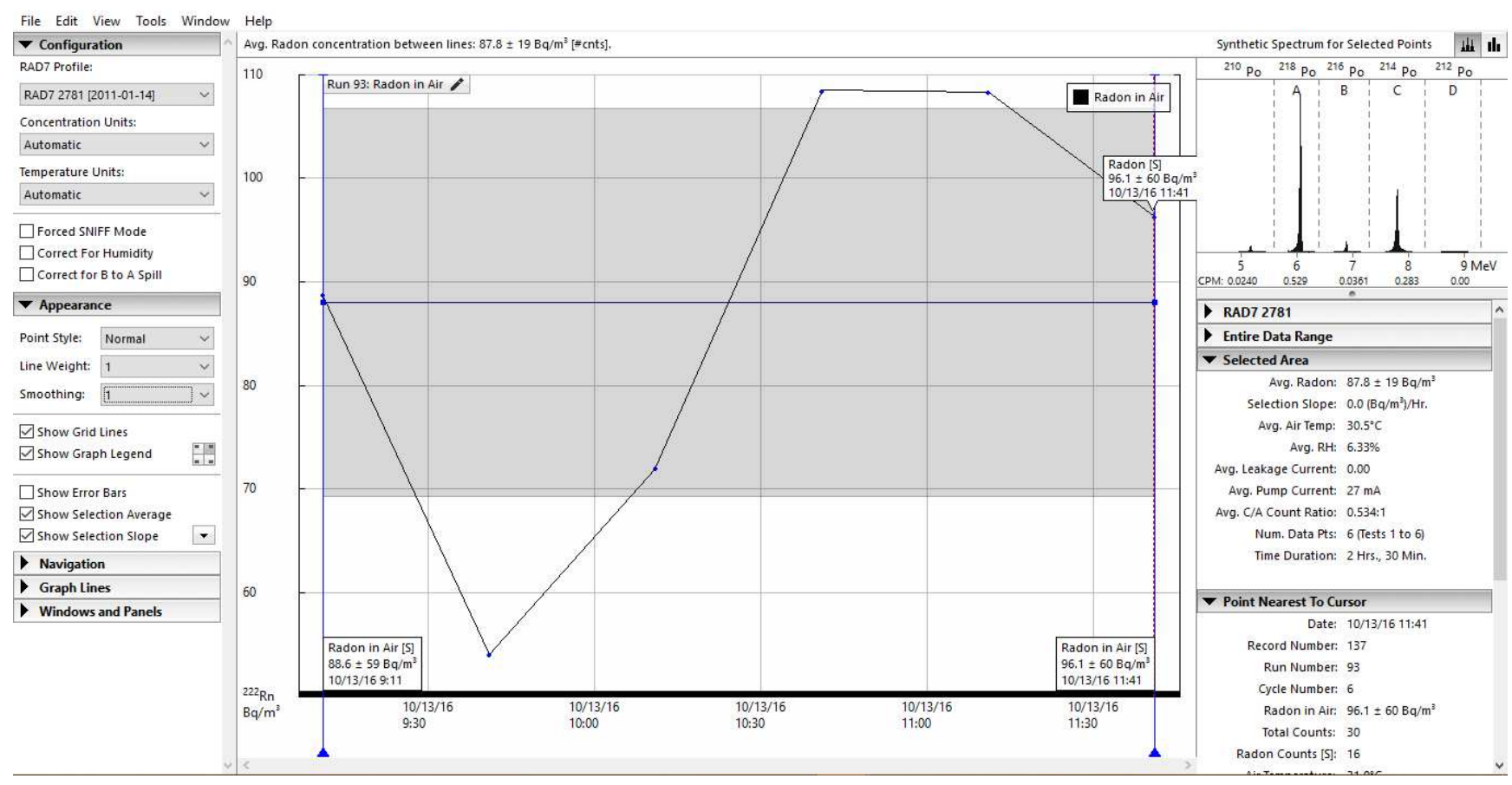

Figure 6. Shows a reading using capture software.

\subsection{The Radon Measurement for Air Samples}

In case of measuring radon in air the sampled air enters an interaction chamber and the relative humidity, temperature and battery voltage are all parameters that are worth observing.

Three hours counts had been used for measuring the radon activity in which The RAD-7 pumps the air for 5 minutes into the cell of the detector, and only then counts for 5 minutes and so on... Until the three hours finished. During the three hours each radon daughters had been detected were placed on the surface of the detector and then decay, then emit alpha particles into the solid state detector as shown in figure 7, after that it's converted into an electric signal. In the present study, the measurement was recorded by using a continuous 1-day protocol. Grab protocol may not give an accurate value of the radon levels because radon concentrations change significantly and rapidly. The RAD7 
detector collects the $\alpha$-emitters electrostatically and analyses them spectrally. Ambient air is sucked in by a pump at a rate of $11 / \mathrm{min}$, and passes through a drierite/desiccant and filter prior to entering the solid-state detector, which measures the concentration of radon [33].

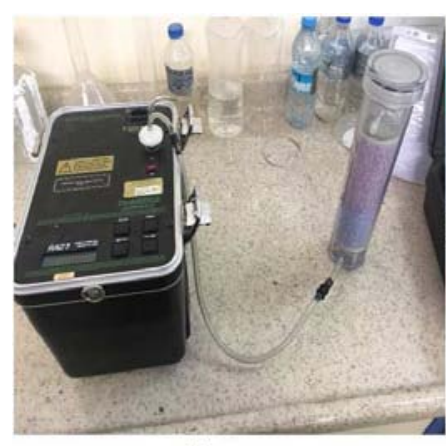

(a)

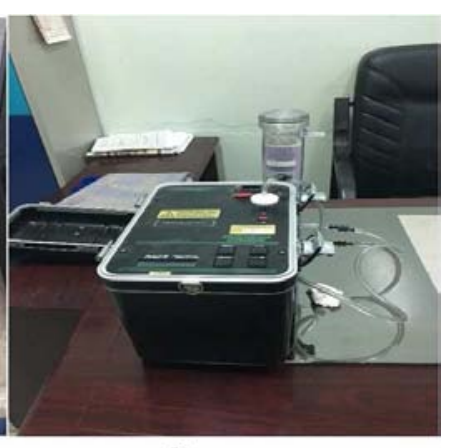

(b)

Figure 7. (a, b) A photos for two of the measurement for air samples.

\subsection{Running a 1-Day Test with RAD7}

In order to do any test in the RAD7 we have to go through a five step process, we will through:
(a). Equipment
(b). Setup
(c). Purge
(d). Configuration
(e). Test

Table 2. Shows the different protocols and their properties.

\begin{tabular}{llllll}
\hline Protocol & Cycle & Re cycle & Mode & Thoron & Pump \\
\hline sniff & $00: 05$ & 0 & Sniff & Off & Auto \\
1-day & $00: 30$ & 48 & Auto & Off & Auto \\
2-day & $01: 00$ & 48 & Auto & Off & Auto \\
weeks & $02: 00$ & 0 & Auto & Off & Auto \\
User & xxx & xxx & xxx & xxx & xxx \\
Grab & $00: 05$ & 4 & Sniff & Off & Grab \\
Wat-40 & $00: 05$ & 4 & Wat-40 & Off & Grab \\
Wat 250 & $00: 05$ & 4 & Wat 250 & Off & Grab \\
Thoron & $00: 05$ & 0 & Sniff & On & Auto \\
\hline
\end{tabular}

When we are done, we will be able to review the results of the test on a printed out piece of paper from the portable printer, or downloaded on our computer through durridge capture software as we explained it above. Before we begin the test we should know that the Rad7 has several "protocols" programmed into it in order to run tests of different lengths as shown in table 2 . These include a sniff-test which allows us to make a quick survey of radon levels, a longer 2- day test which complies with EPA (environmental protection agency) standards of testing.

According to our measurement for radon in air we did use the 1-day protocol but kept it running for three hours only which is enough to reach approximately the full equilibrium between Po-218 (new radon) and Po-214 (old radon). So first we prepare the equipment that we need to run the test which is the power cable as shown in figure 10.a, a small white inlet filter as shown in figure 10.b that goes into the inlet knob of the $\operatorname{Rad} 7$ which then connects to an arm's length piece of vinyl tubing with a $1 / 8$ adaptor on one end, and a 5/16 adaptor on the other that goes into the laboratory desiccant as shown in figure 10.c, a forearm's length tube that contains drierite for dehumidifying air as shown in figure 10.d.

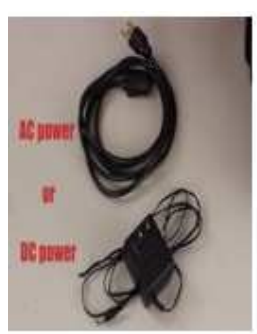

(a)

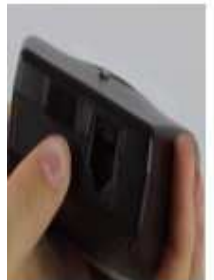

(e)

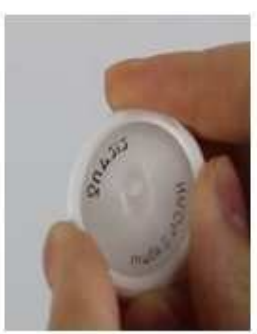

(b)

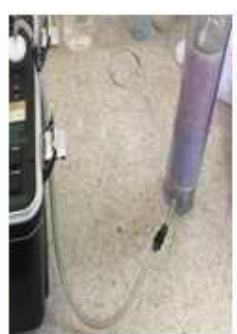

(c)

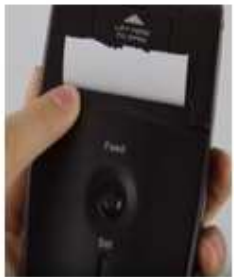

(f)

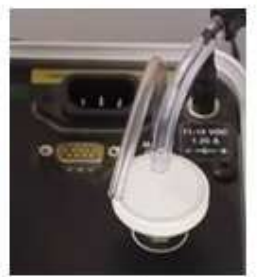

(g)

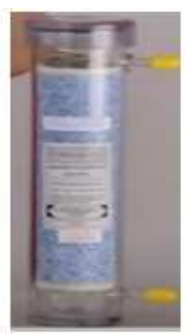

(d)

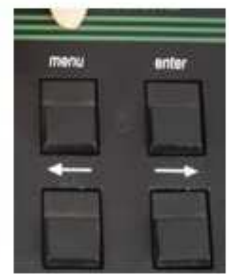

(h)

Figure 8. Shows the different equipment to run a 1-day test. The power cable (a), inlet filter (b), an arm's length piece of vinyl tubing (c), a laboratory desiccant (d), the infrared window (e), the printer (f), the link between the inlet filter with the inlet knob of the Rad7 ( $g$ ), The buttons that showing command and configure the RAD7 (h). 
Lastly, we need the potable infrared printer and its infrared window is located on the bottom of the printer as shown in figure 10.e where we receive signals from the $\operatorname{Rad} 7$ in order to print out the results on thermal paper as shown in figure 10.f it runs on $4 \mathrm{~A}$ batteries.

Now we begin to use the equipment to set up the RAD7 for the test. First we take the power cable, and plug it in to a power supply. Next, we take the yellow caps off the drierite desiccant, and putting them somewhere for later use. Next we take the 5/16 adapter from the vinyl tubing, and plug it in to the bottom inlet of the desiccant and take the other end of the tube and plug it in to the white inlet filter then we take the filter and plug it in to the inlet knob of the RAD7 as shown in figure 10.g Now we take the portable printer and turn it on using the button on the side then we put it on the top of the Rad7 so that the infrared window lines up with LED it should be in this ideal area in order to communicate with the RAD7.

Now we can turn it on. At start up, the LED screen displays the RAD7 identification details and the current setup protocol while the printer starts printing a header on the paper we can hit the button "menu" to skip through the intro and display "test". The buttons that showing command and configure the RAD7: menu, enter, the left and the right arrows as shown in fig. (10.h).

Before starting the 1-day radon test, we need to run a "purge" in order to rid the RAD7's inner chamber of moisture and radon gas remaining from previous use and the best location to do this is outdoors. In the RAD7 menu, the four top-level options are Test, Data, setup and special. We hit the arrow keys to go through and then we click enter to select, so we can go through more options we can click the menu button to go back. So, if we want to purge the device, from test we click enter then find purge and click enter we should hear the pump start. The RAD7 is now drawing in air through the desiccant into the chamber and then exhausting it through the outlet. The LED screen will show "stop purge? No", but we don't click enter until we are ready to stop the purge after 5 minutes of purging, we click the right arrow to see "yes" on the screen, then we click enter to stop the purge. To configure the RAD7 for out test, we need to select the 1day protocol using the menu and buttons. From Test, we click the right arrow key twice to see setup, then click the first option which is the protocol option, now we click enter again and we can choose from among 7 different options of preprogrammed testing protocols, or customize our own. To run a 1-day test, we click 1-day. This means that the RAD7 will take 30 minute reading for a 24 hour run: it will complete 48 half-hour cycles.

Now we are ready to run the test by bring it to the location that we wish to measure then we click "enter" on the "test" and we click the right arrow to see start, then enter. We can hear the pump start, by pushing the arrow keys we can see the various active status windows. In the third window we can see the internal temperature, relative humidity, current battery voltage, and the pump current, we can watch how the relative humidity goes down the pump will continuously run until this value drops below $10 \%$, then it falls into regular intervals according to the 1-day protocol. So, after 24 hours, the RAD7 is done its 1-day run and there is now a printed log that shows the status of the RAD7 prior to beginning the run, a print out for each half-hour cycle, and the run summary, including average radon concentration, a bar graph, and more. If the results shows a high concentration of radon, we should purge the RAD7 the same way it was done in the "purge" section, then we can turn it off.

\subsection{The Measurement Principle of RAD7}

In our measurement for radon in air we did choose the 1day protocol which uses the auto mode, as we explained the AUTO mode automatically switches from SNIFF mode to NORMAL mode after three hours of continuous measurement, but our measurement is only three our hours so the applied mode is sniff mode so as the soil radon measurement which we use directly the sniff mode.

If the RAD7 uses the sniff mode to measure the radon concentration, the counts of particle emitted by ${ }^{218} \mathrm{Po}$ is used to express radon concentration. The progeny of radon is filtrated, while the radon is sniffed into RAD7. The differential equations of the radon decay series in the internal cell of RAD7 are as follows:

$$
\begin{gathered}
\frac{d C(t)}{d t}=-\lambda C(t) \\
\frac{d C_{p o}(t)}{d x}=\lambda_{p o} C(t)-\lambda_{p o} C_{p o}(t)
\end{gathered}
$$

Where $\mathrm{Ct}()$ is the radon concentration in the internal cell of RAD7, $\lambda$ is the decay constant of radon, Cpo (t) is $218 \mathrm{Po}$ concentration, and $\lambda \mathrm{Po}$ is $218 \mathrm{Po}$ decay constant and equals to $0.0037 \mathrm{~s}-1$. After a certain time of pumping, the radon concentration in internal cell of RAD7 equals to that of the environment $\mathrm{C} 0$. Equation (2) can be rewritten as: [34, 35]

$$
d C_{P o}(t) d t=\lambda_{p o} C_{0}-\lambda_{P o} C_{P o}(t)
$$

The initial condition is:

$$
C_{P o}(0)=0
$$

The solution of Equation (3) is:

$$
C_{P o}(t)=C_{0}\left(1-e^{-\lambda_{P o} t}\right.
$$

If the time is much longer than the half-life of $218 \mathrm{Po}$, Equation (5) can be rewritten as:

$$
C_{P o}(t)=C_{0}
$$

Radon concentration can be obtained from Equation (6), and this is the measurement principle of RAD7.

\subsection{Estimation the Effective Dose Equivalent Rate and the Annual Effective Dose from the Radon-222 Activities}

Due to its inert properties the noble gas radon is not 
chemically bound in body tissues. Thus the specific 222Rnactivity $\left(\mathrm{a}_{\mathrm{T}}\right)$ in a tissue $\mathrm{T}$ is limited by its saturation solubility which is proportional to the activity concentration $\mathrm{C}_{\mathrm{air}}$ of ${ }^{222} \mathrm{Rn}$ in the environmental air [36]:

$$
\mathrm{a}_{\mathrm{T}}\left(\mathrm{Bq} \mathrm{Kg}^{-1}\right)=\frac{L_{T}}{\rho_{T}\left(\mathrm{Kgm}^{-3}\right)} \cdot\left(C_{\text {air }}\right)\left(B q \mathrm{~m}^{-3}\right)
$$

In this equation $\rho_{\mathrm{T}}$ is the tissue density and $\mathrm{L}_{\mathrm{T}}$, is Ostwald's solubility factor, which is defined as the volumetric saturation ratio of the Rn-concentration in the tissue $\mathrm{T}$ relative to air. The solubility factor $\mathrm{L}_{\mathrm{T}}$, of riskrelevant soft tissues for radon lies in the range of 0.3-0.5. With a mean value of $\mathrm{L}_{\mathrm{T}}=0.4$ and $\rho_{\mathrm{T}}=\left(1 \mathrm{~g} . \mathrm{cm}^{-3}\right)=\left(10^{3} \mathrm{~kg}\right.$. $\left.\mathrm{m}^{-3}\right)$ it follows that for these tissues the specific equilibrium activity from dissolved ${ }^{222} \mathrm{Rn}$ is:

$$
\mathrm{a}_{\mathrm{T}}\left(\mathrm{Bq} \mathrm{Kg}^{-1}\right) \approx 0.410^{-3} \cdot\left(\mathrm{C}_{\text {air }}\right)\left(\mathrm{Bq} \mathrm{m}^{-3}\right)
$$

In the case of the lungs in addition to the dissolved radon the radon content of the lung air has to be taken into account. Due to the rapid air mixing between the tidal volume and the functional residual capacity a total Rn-filled air volume in the lungs of about $3.210^{-3} . \mathrm{m}^{3}$ can be assumed for Reference Man. With this assumption the total Rn-activity in the lung ( $\mathrm{Rn}$ in tissue and air) becomes:

$$
\begin{aligned}
\mathrm{a}_{\text {lung }}\left(\mathrm{Bq} \mathrm{Kg}^{-1}\right) & \approx\left(0.4 * 10^{-3}+3.2 * 10^{-3}\right) .\left(\mathrm{C}_{\text {air }}\right)\left(\mathrm{Bq} \mathrm{m}^{-3}\right) \\
& \approx 3.6 * 10^{-3} *\left(\mathrm{C}_{\text {air }}\right)\left(\mathrm{Bq} \mathrm{m}^{-3}\right)
\end{aligned}
$$

The short-lived daughter atoms produced are assumed to decay in the same tissue as their mother atom. Inserting a quality factor $\mathrm{Q} \alpha=20$ for $\alpha$ radiation the committed effective energy per 222Rn-transformation becomes Eeff $=\mathrm{Q} \alpha$. 19.2 $\mathrm{MeV}=384 \mathrm{MeV}=0.62 .10-10 \mathrm{~J}$. To a first approximation the same value may be applicable for Rn-atoms decaying in the lung air, because most of the 218Po (RaA)-atoms formed in lung air will be deposited in the lung. For equilibrium conditions the dose-equivalent rate follows from the relation:

$$
\begin{aligned}
H_{T}\left(S v h^{-1}\right) & \approx 3.610^{3} \frac{s}{h} \cdot E_{e f f}(J) \cdot a_{T}\left(B q K g^{-1}\right) \\
& \approx 2.210^{-1} \cdot a_{t}\left(B q K g^{-1}\right)
\end{aligned}
$$

Inserting equations (2 and 3 ) in (4) one obtains for the lung:

$$
H_{\text {Lung }}\left(S v h^{-1}\right) \approx 810^{-10} \cdot\left(C_{\text {air }}\right)\left(B q m^{-3}\right)
$$

And for other risk-relevant soft tissues:

$$
H_{\text {othertissues }}\left(\mathrm{Svh}^{-1}\right) \approx 0.910^{-1} \cdot\left(C_{\text {air }}\right)\left(\mathrm{Bqm}^{-3}\right)
$$

So the dose received by the soft tissue and the lung are:

$$
\begin{gathered}
\mathrm{D}_{\text {Soft tissue }}\left(\mathrm{nGyh}^{-1}\right)=0.005 \mathrm{X}_{\mathrm{RnAir}}\left(\mathrm{Bq} \mathrm{m}^{-3}\right) \\
\mathrm{D}_{\text {lung }}\left(\mathrm{nGyh}^{-1}\right)=0.04 \mathrm{X}_{\text {RnAir }}\left(\mathrm{Bq} \mathrm{m}^{-3}\right)
\end{gathered}
$$

Where $\left(\mathrm{X}_{\mathrm{RnAir}}\right)$ is the concentration of radon. Applying a weighting factor $\mathrm{W}_{\mathrm{T}}=0.12$ for the lungs and $\mathrm{W}_{\mathrm{T}}=0.88$ for the other risk-relevant tissues an effective dose - equivalent rate:

$$
\begin{aligned}
H_{E}\left(S v h^{-1}\right) \approx & \left(0.12 * 810^{-10}+0.88\right. \\
& \left.* 0.910^{-10}\right)\left(C_{\text {air }}\right)\left(B^{-3} m^{-3}\right) \\
\approx & 1.810^{-10} \cdot\left(C_{\text {air }}\right)\left(B_{\text {qm }}{ }^{-3}\right)
\end{aligned}
$$

Since the radon is the main reason of lung cancer among people who have never smoked it's important to calculate the annual effective dose [37]:

$$
A E D(m S v / y)=C_{-} R n * F * O *(D C F)
$$

Where the:

AED: The annual effective dose

$\mathrm{C}_{\mathrm{Rn}}$ : The activity of indoor radon in $\mathrm{Bq} / \mathrm{m}^{3}$.

$\mathrm{F}$ : The global average of equilibrium factor for radon and its descendant for outdoor (0.6) and indoor (0.4)

O: The global average occupancy factor for indoor $(7000$ h. $\mathrm{y}^{-1}$ ) and outdoor (1760 h. $\left.\mathrm{y}^{-1}\right)$.

\begin{tabular}{|c|c|c|c|c|}
\hline \multirow{2}{*}{ No. } & \multirow{2}{*}{ Sample Point no. } & \multirow{2}{*}{ location } & \multicolumn{2}{|c|}{ GPS Coordinates } \\
\hline & & & $\boldsymbol{E}$ & $N$ \\
\hline 1 & $\mathrm{P} 1$ & Radiological and Nuclear Safety Directorate $\backslash$ Equipment storage & 44.51349 & 33.207 \\
\hline 2 & $\mathrm{P} 2$ & Central Laboratories Directorate $\backslash$ sample preparation room & 44.512924 & 33.207395 \\
\hline 3 & P3 & Radiological and Nuclear Safety Directorate $\backslash$ sample preparation room & 44.51339 & 33.20694 \\
\hline 4 & P4 & Treatment of Radioactive Waste Management Directorate $\backslash$ control cameras room & 44.517862 & 33.20185 \\
\hline 5 & P5 & Scientific Information Center (Central Library) \Basement & 44.512924 & 33.20739 \\
\hline 6 & P6 & Nuclear applications Directorate & 44.509423 & 33.20605 \\
\hline 7 & P7 & Radiation and Nuclear Safety Directorate $\backslash$ second building & 44.512697 & 33.20803 \\
\hline 8 & P8 & Radiological and Nuclear Safety Directorate $\backslash$ Department of nuclear safety & 44.512987 & 33.20672 \\
\hline 9 & P9 & Department of Agriculture $\backslash$ Laboratory fertilizer & 44.51632 & 33.20703 \\
\hline 10 & P10 & Ishtar $\backslash$ alttakhi school & 44.53204 & 33.19256 \\
\hline 11 & P11 & Decommissioning Directorate $\backslash$ equipment storage & 44.5177 & 33.20509 \\
\hline
\end{tabular}

DCF: The dose conversion factor $\left(9 \mathrm{nSv} / \mathrm{h}\right.$ per $\left.\mathrm{Bq} / \mathrm{m}^{3}\right)$

\subsection{Location and Collection of the Samples}

In the present study twenty locations as fair distribution for Al-Tuwaitha nuclear site and some surrounding areas were chosen for radon measurements (twenty for air samples during hot months and twenty for air samples during cold months). The regions were determined and drawn by using (GPS) technique as shown in Figure 9 for air samples. Table 3 shows the sites studied for indoor air at Al-Tuwaitha nuclear site and the surrounding areas. The chosen locations varied between Administrative buildings, radiological laboratories, radiological storages and houses.

Table 3. The studied sites for indoor radon in air. 


\begin{tabular}{|c|c|c|c|c|}
\hline \multirow{2}{*}{ No. } & \multirow{2}{*}{ Sample Point no. } & \multirow{2}{*}{ location } & \multicolumn{2}{|c|}{ GPS Coordinates } \\
\hline & & & $E$ & $N$ \\
\hline 12 & P12 & The Organization presidency \room & 44.51703 & 33.20592 \\
\hline 13 & $\mathrm{P} 13$ & Decommissioning Directorate $\backslash$ emergency room & 44.5174 & 33.205 \\
\hline 14 & P14 & Al-alearifih $\backslash$ Salam neighborhood & 44.55268 & 33.20885 \\
\hline 15 & P15 & Jisr Diyala $\backslash$ Riyadh & 44.52725 & 33.2247 \\
\hline 16 & P16 & Management and Treatment of Radioactive Waste /meeting room & 44.517862 & 33.20185 \\
\hline 17 & P17 & Jisr Diyala $\backslash$ area of energy storage & 44.531385 & 33.22133 \\
\hline 18 & P18 & Jisr Diyala $\backslash$ Riyadh 70 Street & 44.52722 & 33.2243 \\
\hline 19 & P19 & Alwardia $\backslash$ Secondary of alnnabi yahyaa & 44.54756 & 33.18242 \\
\hline 20 & $\mathrm{P} 20$ & Alwardia area /aljiearah clinic & 44.5518 & 33.17725 \\
\hline
\end{tabular}

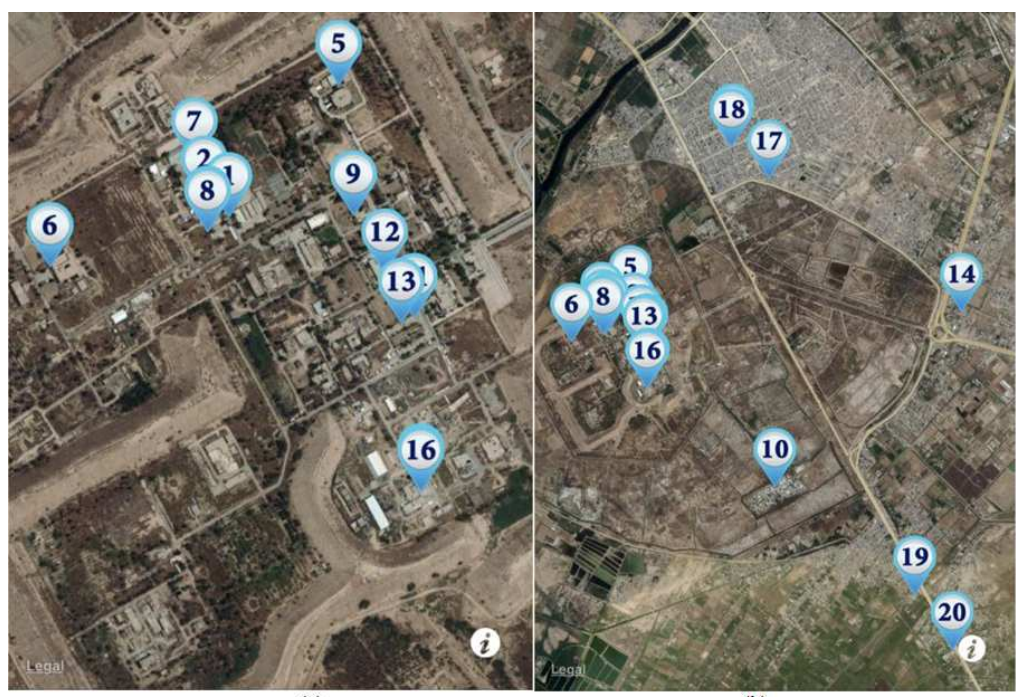

(a)

(b)

Figure 9. (a) Aerial photo for Al-Tuwaitha Nuclear Site and the surrounding areas shows location of the indoor air radon measurement. (b) Enlarged photo for Al-Tuwaitha nuclear site that shows the indoor radon measurements.

\section{Results and Discussion}

The indoor radon concentration had been measured for 3 hours in twenty locations at Al-Tuwaitha nuclear site and some surrounding locations in cold and hot months. Table 4 and 5 shows the concentrations of radon in these locations. Also these tables illustrates the RAD eye background in $(\mu \mathrm{Sv} / \mathrm{h})$ and air temperature. Figure 10 shows Indoor Radon concentrations as a function for location.

Table 4. Indoor radon concentrations at deferent locations during hot months.

\begin{tabular}{lllll}
\hline Sample Point no. & Date & RAD eye $(\boldsymbol{\mu} \mathbf{S v} / \mathbf{h})$ & Weather Temperature $\left({ }^{\circ} \mathbf{C}\right)$ & Indoor radon concentrations $\left(\mathbf{B q} / \mathbf{m}^{3}\right)$ \\
\hline P1 & $13 / 10 / 2016$ & 0.05 & 31 & $87.8 \pm 19$ \\
P2 & $16 / 10 / 2016$ & 0.02 & 25.5 & $4.96 \pm 4.4$ \\
P3 & $17 / 10 / 2016$ & 0.04 & 31.3 & $7.78 \pm 5.6$ \\
P4 & $18 / 10 / 2016$ & 0.03 & 30 & $31.8 \pm 18$ \\
P5 & $20 / 10 / 2016$ & 0.03 & 31.3 & $35.9 \pm 15.1$ \\
P6 & $23 / 10 / 2016$ & 0.02 & 30.4 & $18.5 \pm 9$ \\
P7 & $24 / 10 / 2016$ & 0.03 & 30.1 & $31.6 \pm 11$ \\
P8 & $25 / 10 / 2016$ & 0.02 & 28.6 & $18.5 \pm 9$ \\
P9 & $27 / 10 / 2016$ & 0.03 & 28.9 & $17.7 \pm 8$ \\
P10 & $31 / 10 / 2016$ & 0.02 & 27.7 & $11.8 \pm 4$ \\
P11 & $2017 / 5 / 16$ & 0.05 & 33.3 & $.8 \pm 57$ \\
P12 & $2017 / 5 / 21$ & 0.05 & 30.9 & $14.8 \pm 6$ \\
P13 & $2017 / 5 / 14$ & 0.07 & 30.1 & $23.6 \pm 11$ \\
P14 & $2017 / 5 / 17$ & 0.03 & 35.8 & $14.8 \pm 6$ \\
P15 & $2017 / 5 / 18$ & 0.02 & 34.1 & $5.90 \pm 5$ \\
P16 & $2017 / 5 / 15$ & 0.04 & 32.9 & $35.4 \pm 10$ \\
P17 & $2017 / 5 / 24$ & 0.05 & 32.4 & $5.96 \pm 4.4$ \\
P18 & $2017 / 5 / 25$ & 0.05 & 34.5 & $23.6 \pm 17$ \\
P19 & $2017 / 5 / 22$ & 0.02 & 31.9 & $5.91 \pm 5.1$ \\
P20 & $2017 / 5 / 23$ & 0.06 & 31.9 & $5.90 \pm 5$ \\
\hline
\end{tabular}


Table 5. Indoor radon concentrations at deferent locations during cold months.

\begin{tabular}{lllll}
\hline Sample Point no. & Date & RAD eye $(\boldsymbol{\mu} \mathbf{S v} / \mathbf{h})$ & Weather temperature $\left({ }^{\circ} \mathbf{C}\right)$ & Indoor radon concentrations $\left(\mathbf{B q} / \mathbf{m}^{3}\right)$ \\
\hline P1 & $2016 / 12 / 27$ & 0.05 & 20 & $90.2 \pm 16$ \\
P2 & $2016 / 12 / 28$ & 0.02 & 18.1 & $11 \pm 8$ \\
P3 & $2016 / 12 / 29$ & 0.04 & 18 & $14.8 \pm 7.62$ \\
P4 & $2017 / 1 / 9$ & 0.03 & 17 & $47.2 \pm 13$ \\
P5 & $2017 / 1 / 3$ & 0.03 & 19.7 & $42.8 \pm 16$ \\
P6 & $2017 / 1 / 5$ & 0.02 & 18.2 & $39.4 \pm 18$ \\
P7 & $2017 / 1 / 4$ & 0.03 & 17.2 & $34 \pm 14$ \\
P8 & $2017 / 1 / 8$ & 0.02 & 20 & $53.8 \pm 18$ \\
P9 & $2017 / 1 / 10$ & 0.03 & 17.3 & $29.5 \pm 8$ \\
P10 & $2017 / 1 / 11$ & 0.02 & 16.5 & $20.3 \pm 9$ \\
P11 & $2016 / 12 / 7$ & 0.05 & 18.5 & $10.6 \pm 7$ \\
P12 & $2016 / 12 / 12$ & 0.05 & 16.6 & $19.2 \pm 11$ \\
P13 & $2016 / 12 / 13$ & 0.07 & 16.7 & $102 \pm 25$ \\
P14 & $2016 / 12 / 14$ & 0.03 & 15.1 & $44.3 \pm 16$ \\
P15 & $2016 / 12 / 15$ & 0.02 & 17.2 & $10.9 \pm 8$ \\
P16 & $2016 / 12 / 6$ & 0.04 & 19.2 & $41.3 \pm 16$ \\
P17 & $2016 / 12 / 22$ & 0.05 & 13.7 & $26.6 \pm 13$ \\
P18 & $2016 / 12 / 19$ & 0.05 & 16.4 & $25.1 \pm 12$ \\
P19 & $2016 / 12 / 26$ & 0.02 & 15.5 & $11.8 \pm 8$ \\
P20 & $2017 / 1 / 2$ & 0.06 & 17.9 & $25.1 \pm 12$ \\
\hline
\end{tabular}

It was found that the higher activity of radon was $(102 \pm 25$ $\left.\mathrm{Bq} / \mathrm{m}^{3}\right)$ with temperature $\left(16.7^{\circ} \mathrm{C}\right)$ in the Decommissioning Directorate /emergency room which was a small room compared with the other locations, the walls were covered with Ceramic material, there wasn't any kind of cracks or windows and the door were tightly closed. The low activity was $\left(4.96 \pm 4.4 \mathrm{~Bq} / \mathrm{m}^{3}\right)$ with temperature $\left(25.5^{\circ} \mathrm{C}\right)$ in Central Laboratories Directorate $\backslash$ models Room, this low value because of the walls and the ground were covered with a plastic material which minimize the emission of the radon. this variation in the activity of the radon returns to many reasons includes: the air temperature, moisture, the dimensions of the room, the differences in the ventilation system in fact some location doesn't have any ventilation system except the door which we left it close the whole time of measurement, the nature of the building material, the existence of a carpet on the floor of the rooms, the walls covered with a painting material or not all these conditions effects the emission of the radon.

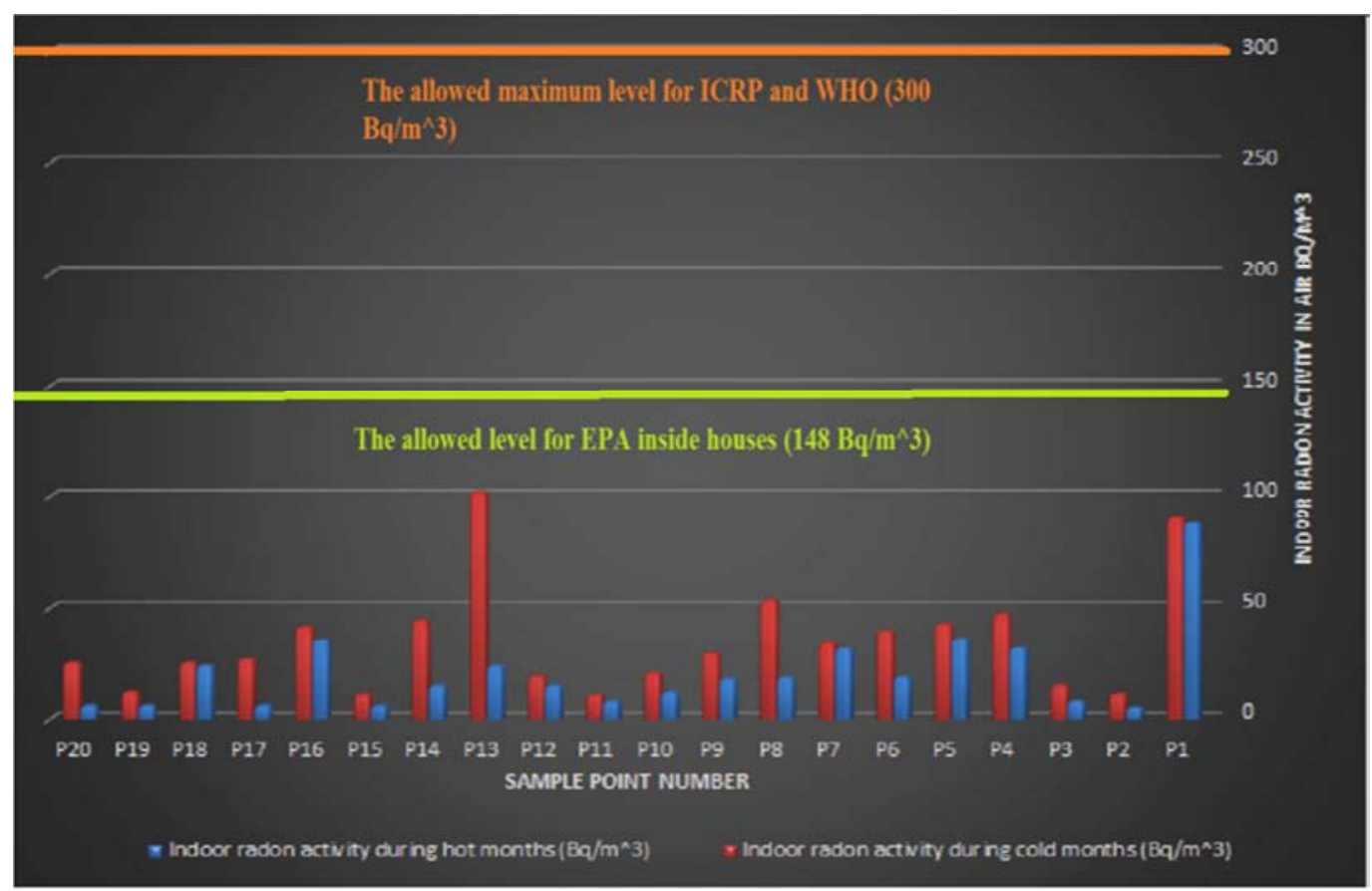

Figure 10. Indoor radon activities during hot and cold months as a function of location.

It is clear that the detected concentration values of indoor ${ }^{222} \mathrm{Rn}$ in some locations is higher than the median values of $\left(46 \mathrm{~Bq} / \mathrm{m}^{3}\right)$ in dwelling. But the average value is well below the action level suggested by the US Environmental Protection Agency (EPA) $\left(148 \mathrm{~Bq} / \mathrm{m}^{3}\right)$ inside houses [38]. On the other hand, the WHO (world health organization) 
suggested that countries adopt reference levels for the indoor radon of $\left(100 \mathrm{~Bq} / \mathrm{m}^{3}\right)$, and recommends for the public health that the reference level should not go beyond $300 \mathrm{~Bq} / \mathrm{m}^{3}$ if that level cannot be fulfilled [39]. The (ICRP) International Commission on Radiological Protection has therefore reviewed the higher value for the reference level for radon gas in dwellings from the level in the 2007 Recommendations of $\left(600 \mathrm{~Bq} / \mathrm{m}^{3}\right)$ to $\left(300 \mathrm{~Bq} / \mathrm{m}^{3}\right)$.

The dissolved in soft tissues and dose rate due to alpha- radiation in the lung formed from the radon gas inhalation samples is listed in Table (6 and 7) and calculated using equation (7). The average dissolved in soft tissues range from 0.0248 to $0.51\left(\mathrm{nGyh}^{-1}\right)$. The average dose rate due to alpharadiation in the lung formed from the radon gas inhalation samples was calculated using equation (8) and varied from 0.1984 to $4.08\left(\mathrm{nGyh}^{-1}\right)$. The effective dose - equivalent rate was calculated using equation (9) and ranged from 0.8928 to $18.36(\mathrm{nSv} / \mathrm{h})$.

Table 6. Indoor radon's concentration and Variation of dose relationship from indoor radon measurements from air during the hot months at Al-Tuwaitha nuclear site.

\begin{tabular}{|c|c|c|c|c|}
\hline Sample point no. & $D_{\text {soft tissues }}(\mathrm{nGy} / \mathrm{h})$ & $\mathbf{D}_{\text {Lung }}(\mathrm{nGy} / \mathbf{h})$ & $\mathrm{H}_{\text {eff }}(\mathrm{nSv} / \mathrm{h})$ & Annual effective dose $(\mathrm{mSv} / \mathrm{y})$ \\
\hline $\mathrm{P} 1$ & 0.439 & 3.512 & 15.804 & 2.21256 \\
\hline P2 & 0.0248 & 0.1984 & 0.8928 & 0.124992 \\
\hline P3 & 0.0389 & 0.3112 & 1.4004 & 0.196056 \\
\hline P4 & 0.159 & 1.272 & 5.724 & 0.80136 \\
\hline P5 & 0.1795 & 1.436 & 6.462 & 0.90468 \\
\hline P6 & 0.0925 & 0.74 & 3.33 & 0.4662 \\
\hline P7 & 0.158 & 1.264 & 5.688 & 0.79632 \\
\hline P8 & 0.0925 & 0.74 & 3.33 & 0.4662 \\
\hline P9 & 0.0885 & 0.708 & 3.186 & 0.44604 \\
\hline P10 & 0.059 & 0.472 & 2.124 & 0.29736 \\
\hline P11 & 0.039 & 0.312 & 1.404 & 0.19656 \\
\hline P12 & 0.074 & 0.592 & 2.664 & 0.37296 \\
\hline P13 & 0.118 & 0.944 & 4.248 & 0.59472 \\
\hline P14 & 0.074 & 0.592 & 2.664 & 0.37296 \\
\hline P16 & 0.177 & 1.416 & 6.372 & 0.89208 \\
\hline P17 & 0.0298 & 0.2384 & 1.0728 & 0.150192 \\
\hline P18 & 0.118 & 0.944 & 4.248 & 0.59472 \\
\hline P19 & 0.02955 & 0.2364 & 1.0638 & 0.148932 \\
\hline P20 & 0.0295 & 0.236 & 1.062 & 0.14868 \\
\hline Min & 0.0248 & 0.1984 & 0.8928 & 0.124992 \\
\hline $\operatorname{Max}$ & 0.439 & 3.512 & 15.804 & 2.21256 \\
\hline Average & 0.1025025 & 0.82002 & 3.69009 & 0.5166126 \\
\hline
\end{tabular}

Table 7. Indoor radon's concentration and Variation of dose relationship from indoor radon measurements from air during cold months at Al-Tuwaitha nuclear site.

\begin{tabular}{|c|c|c|c|c|}
\hline Sample point no. & $D_{\text {soft tissues }}(\mathrm{nGy} / \mathrm{h})$ & $D_{\text {Lung }}(\mathrm{nGy} / \mathrm{h})$ & $H_{\text {eff }}(n S v / h)$ & Annual effective dose $(\mathrm{mSv} / \mathrm{y})$ \\
\hline P1 & 0.451 & 3.608 & 16.236 & 2.27304 \\
\hline $\mathrm{P} 2$ & 0.055 & 0.44 & 1.98 & 0.2772 \\
\hline P3 & 0.074 & 0.592 & 2.664 & 0.37296 \\
\hline P4 & 0.236 & 1.888 & 8.496 & 1.18944 \\
\hline P5 & 0.214 & 1.712 & 7.704 & 1.07856 \\
\hline P6 & 0.197 & 1.576 & 7.092 & 0.99288 \\
\hline P7 & 0.17 & 1.36 & 6.12 & 0.8568 \\
\hline P8 & 0.269 & 2.152 & 9.684 & 1.35576 \\
\hline P9 & 0.1475 & 1.18 & 5.31 & 0.7434 \\
\hline P10 & 0.1015 & 0.812 & 3.654 & 0.51156 \\
\hline P11 & 0.053 & 0.424 & 1.908 & 0.26712 \\
\hline P12 & 0.096 & 0.768 & 3.456 & 0.48384 \\
\hline P13 & 0.51 & 4.08 & 18.36 & 2.5704 \\
\hline P14 & 0.2215 & 1.772 & 7.974 & 1.11636 \\
\hline P15 & 0.0545 & 0.436 & 1.962 & 0.27468 \\
\hline P17 & 0.133 & 1.064 & 4.788 & 0.67032 \\
\hline P18 & 0.1255 & 1.004 & 4.518 & 0.63252 \\
\hline P19 & 0.059 & 0.472 & 2.124 & 0.29736 \\
\hline P20 & 0.1255 & 1.004 & 4.518 & 0.63252 \\
\hline Min & 0.053 & 0.424 & 1.908 & 0.26712 \\
\hline Max & 0.51 & 4.08 & 18.36 & 2.5704 \\
\hline Average & 0.174975 & 1.3998 & 6.2991 & 0.881874 \\
\hline
\end{tabular}


As we can see in Table 6, 7 which shows the Variation of dose relationship from radon measurements for indoor air at Al-Tuwaitha nuclear site and some surrounding locations. The values of the annual effective doses for radon inhalation by the people were calculated and ranged from $(0.124992$ to 2.5704) $\mathrm{mSv} / \mathrm{y}$ these result are lower than the value of $(10$ $\mathrm{mSv} / \mathrm{y}$ ) recommended by the ICRP (International Commission on Radiological Protection) The values are found to be within the safe limits as recommended by ICRP $(1993,1981)$. The results showed that these areas are safe from the health hazard point of view as far as the radon is concerned.

Since there is no recognized hazardous level of radon, and there is always be some risk that can be reduced by lowering the radon level in the chosen location this can be done by using a vent pipe system and fan, which pulls radon from beneath the location and vent it to the outside. This system known as a soil suction radon reduction system. Sealing foundation cracks and other opening makes this kind of system more operative and Cost-efficient [40].

Since The indoor radon concentrations in several locations in Iraq shows a strong dependence on weather conditions, the comparison of the indoor radon activities between cold and hot months shows that indoor radon activities in cold months exceeds indoor radon activities in hot months. This is because all the chosen locations have a heating system in winter which leads to a pressure difference between indoors (warm places as a result for turning on the heating system) and outdoors (cold weather). This variation in temperature and pressure may lead for pulling the air from outdoor to indoor where the low pressure is found because usually the pressure inside buildings is lower than outdoor and it can get lower when we turn on the furnace or the oven, using the bathroom and Ventilation fans, will decrease the pressure by several Pascal (one pascal equals one newton per square meter) which is enough to pull the air that contains radon from outdoor to indoor as we discussed in section.

\section{Conclusions}

Based on the moveable device RAD7, the indoor air radon concentration values in work places were found to be lower than the action level for IAEA (International Atomic Energy Agency) which is $\left(1000 \mathrm{~Bq} / \mathrm{m}^{3}\right)$ as a yearly average concentration for indoor radon in workplaces.

The indoor air radon concentration values in dwellings were found to be lower than the action level recommended by the US Environmental Protection Agency (EPA) which is $\left(148 \mathrm{~Bq} / \mathrm{m}^{3}\right)$ inside houses.

The variation in the activity of the indoor air radon returns to many causes this includes: the air temperature, moisture, the dimension of the room, the difference in the ventilation system, the nature of the building material. The results of the radon activity concentration from this study shows that the region has background radioactivity levels within the safe limits.
The winter concentration of indoor radon are greater than summer concentrations. The higher amount in the winter is attributed to the observation that people normally keep their windows closed during the winter, allowing indoor radon concentrations to rise. The lower radon concentrations in the summer might occur because people often open their windows, allowing low-radon outside air to enter the home. The annual effective dose (AED), the dose exposed to the soft tissues other than the lungs $\left(\mathrm{D}_{\text {soft tissue }}\right)$, the dose rate due to alpha-radiation in the lung $\left(\mathrm{D}_{\text {lung }}\right)$, the effective dose equivalent rate $\left(\mathrm{H}_{\text {eff }}\right)$ formed from the radon inhalation during the cold months are greater than the doses formed during the hot months.

\section{Acknowledgements}

This project was funded by Al-Tuwaitha nuclear site and the authors would like to thank Zainab Abdul-Zahra Jabr, Hashem hadi saleh, Abbas Al-Ameri and Saliha Husayn Hammid for their hard work.

\section{References}

[1] ICRP "Age dependent Doses to Members of the Public from Intake of Radionuclides" ICRP publication 72; Oxford: Pergamon Press 1996.

[2] Walczak K, Olszewski J, Politański P, Zmyślony M. Int J Occup Med Environ Health. 2017 Jan 18. pii: 64132. doi: 10.13075/ijomeh.1896.00987.

[3] ICRP, 1993. Protection Against Radon-222 at Home and at Work. ICRP Publication 65. Ann. ICRP 23 (2).

[4] Todsadol S., "An Evaluation of the Level of Naturally Occurring Radioactive Materials in Soil samples along the Chao Phraya River Basin", Ph. D. Thesis, University of Surrey, Faculty of Engineering and Physical Sciences, Department of Physics (2012).

[5] WHO Handbook on Indoor Radon: A Public Health Perspective. Geneva: World Health Organization; 2009.

[6] Mentes G, Eper-Pápai I. J Environ Radioact. 2015 Nov; 149: 64-72. doi: 10.1016/j.jenvrad.2015.07.015. Epub 2015 Jul 23. PMID: 26207821.

[7] Kamra L. Appl Radiat Isot. 2015 Nov; 105: 170-5. doi: 10.1016/j.apradiso.2015.08.031. Epub 2015 Aug 20. PMID: 26319089.

[8] Duggal V, Sharma S, Mehra R. Appl Radiat Isot. 2017 May; 123: 36-40. doi: 10.1016/j.apradiso.2017.02.028. Epub 2017 Feb 17.PMID: 28231516.

[9] CU. S. Environmental Protection Agency (2012). A Citizen's Guide to Radon: The Guide to Protecting Yourself and Your Family From Radon.

[10] United Nations Scientific Committee on the Effects of Atomic Radiation (UNSCEAR) Biological Mechanisms of Radiation Actions at Low Doses. A white paper to guide the Scientific Committee's future programme of work. United Nations; New York, NY, USA: 2012. 
[11] Lubin J. Lung cancer risk from residential radon: Metaanalysis of eight epidemiologic studies. J. Natl. Cancer. 1997; 89: 49-57.

[12] Darby S., Hill D., Auvinen A., Barros-Dios J. M., Baysson H., Bochicchio F., Deo H., Falk R., Forastiere F., Hakama M., et al. Radon in homes and risk of lung cancer: Collaborative analysis of individual data from 13 European case-control studies. Br. Med. J. 2005; 330 doi: 10.1136/bmj.38308.477650.63.

[13] Neman R., Hadler N. J. C., Iunes P. J., Paulo S. R. On indoor radon daughters' plate-out on material surfaces. Radiat. Meas. 2005; 39: 653-655.

[14] Kendall G. M., Smith T. J. Doses to organs and tissues from radon and its decay products. J. Radiol. Prot. 2002; 22: 389.

[15] Axelson O. Cancer risks from exposure to radon in homes. Environ. Health Perspect. 1995; 103: 37-43.

[16] Kendall G. M., Smith T. J. Doses to organs and tissues from radon and its decay products. J. Radiol. Prot. 2002; 22: 389.

[17] Farkas A., Hofmann W., Balásházy I., Szoke I., Madas B. G., Moustafa M. Effect of site-specific bronchial radon progeny deposition on the spatial and temporal distributions of cellular responses. Radiat. Environ. Biophys. 2011; 50: 281-297.

[18] Deshpande A., Goodwin E., Bailey S., Marrone B., Lehnert B. Alpha-particle-induced sister chromatid exchange in normal human lung fibroblasts: Evidence for an extranuclear target. Radiat. Res. 1996; 145: 260-267.

[19] Chen D. J., Strniste G. F., Tokita N. The genotoxicity of alpha particles in human embryonic skin fibroblasts. Radiat. Res. 1984; 100: 321-327.

[20] Narayanan P. K., Goodwin E. H., Lehnert B. E. Alpha particles initiate biological production of superoxide anions and hydrogen peroxide in human cells. Cancer Res. 1997; 57: 3963-3971.

[21] Konishi E., Yoshizawa Y. Estimation of depth of basal cell layer of skin for radiation protection. Radiat. Prot. Dosim. 1985; 11: 29-33.

[22] Charles M. Radon exposure of the skin: I. Biological effects. J. Radiol. Prot. 2007; 27: 231-252.

[23] Wheeler B., Allen J., Depledge M., Curnow A. Radon and skin cancer in Southwest England: An ecologic study. Epidemiology. 2012; 23: 44-52.

[24] Al-Zoughool M., Krewski D. Health effects of radon: A review of the literature. Int. J. Radiat. Biol. 2009; 85: 57-69.

[25] Auvinen A., Salonen L., Pekkanen J., Pukkala E., Ilus T., Kurttio P. Radon and other natural radionuclides in drinking water and risk of stomach cancer: A case-cohort study in Finland. Int. J. Cancer. 2005; 114: 109-113.i.

[26] Chesser Ronald K., Brenda E. Rodgers, Mikhail Bondarkov, Esmail Shubber and Carleton J. Phillips, "Piecing together Iraq's nuclear legacy," Bulletin of the Atomic Scientists, May/June, vol. 65, no. 3, pp. 19-33. (2009).
[27] Cochran, J. R., and J. J. Danneels, "Sandia National Laboratories Support of the Iraq Nuclear Facility Dismantlement and Disposal Program", SAND2009-1732, Sandia National Laboratories, Albuquerque, NM., (2009).

[28] Durridge Company Inc., Reference Manual version 6.0.1, RAD7 Electronic Radon Detector, 2010.

[29] Durridge radon instrumentation, $\operatorname{Rad} 7$ electronic radon detector, 2010.

[30] A. C. George. WORLD HISTORY OF RADON RESEARCH AND MEASUREMENT FROM THE EARLY 1900'S TO TODAY. 201-27 26th Avenue Bayside NY 11360 US.

[31] Pant P, Kandari T, Prasad M, Ramola RC. Radiat Prot Dosimetry. 2016 Oct; 171 (2): 212-216. Epub 2016 Mar 30. PMID: 27032779.

[32] Grellier J, Atkinson W, Bérard P, Bingham D, Birchall A, Blanchardon E, Bull R, Canu Guseva I, Challeton-de Vathaire C, Cockerill R, Do MT, Engels H, Figuerola J, Foster A, Holmstock L, Hurtgen C, Laurier D, Puncher M, Riddell AE, Samson E, Thierry-Chef I, Tirmarche M, Vrijheid M, Cardis E. Epidemiology. 2017 May 17. doi: 10.1097/EDE.0000000000000684. PMID: 28520643.

[33] Mohammed D. Alenezy, Radon Concentrations Measurement in Aljouf, Saudi Arabia Using Active Detecting Method, Vol. 6 No. 11, July 2014.

[34] Y Tana, b, D Xiaob, H Yuana, Q Tangb and X Liub, Revision for Measuring the Radon Exhalation Rate From the Medium Surface January 2013 - Journal of Instrumentation, Volume 8, January 2013.

[35] ICRP, 1981. Limits for Inhalation of Radon Daughters by Workers. ICRP Publication 32. Ann. ICRP 6 (1).

[36] UNSCEAR 1982 REPORT, United Nations Scientific Committee on the Effects of Atomic Radiation 1982 Report to the General Assembly.

[37] UNSCEAR, United Nations Scientific Committee on the Effects of Atomic Radiation - Sources and Effects of Ionizing Radiation - UNSCEAR 2000 Report to the General Assembly with scientific Annexes, United Nations, New York. (2000).

[38] National Research Council (US) Committee on Evaluation of EPA Guidelines for Exposure to Naturally Occurring Radioactive Materials. Evaluation of Guidelines for Exposures to Technologically Enhanced Naturally Occurring Radioactive Materials. Washington (DC): National Academies Press (US); (1999).

[39] WHO, World Health Organization; WHO Handbook on Indoor Radon: A Public Health Perspective, Geneva. (2009).

[40] IAEA, International Atomic Energy Agency, Protection of the public against exposure indoors due to radon and other natural sources of radiation. Vienna, (IAEA safety standards series, ISSN 1020-525X; no. SSG-32) (2015). 